\title{
High Arch
}

National Cancer Institute

\section{Source}

National Cancer Institute. High Arch. NCI Thesaurus. Code C124542.

Abnormally raised arch. 